\title{
マグネシウムの熱処理
}

\section{Heattreatment of magnesium}

\section{里 達雄*}

Tatsuo SATO*

\section{1.はじめに}

マグネシウム合金の熱処理は，他の合金と同様，基本的に は材料特性の向上を目的として施される。たとえば，展伸用 合金ではミクロ組織改善，強度・延性バランスの改善，回 復・再結晶組織制御などにより材料特性を向上させ，また， 製品の寸法安定化を図る狙いがある。鋳造用合金においては ミクロ組織や凝固偏析の改善, 強度増大などのほかに鋳造ひ ずみの低減や寸法の安定化を図るため熱処理が行われる。特 に，時効熱処理は展伸用合金および鋳造用合金ともに高強度 化を図る目的で行われる。時効熱処理の場合, 溶体化処理, 焼入れ処理ならびに時効処理が通常施される。これらの各処 理を合金成分に応じて最適に施すことが求められる。

本稿では主として，時効熱処理にかかわる熱処理条件，時 効析出の基本現象，組織变化などについて紹介する。

\section{2. 時効熱処理}

\section{1 各種実用合金の熱処理}

各種実用マグネシウム合金，すなわち，鋳造用合金および 展伸用合金（押出用合金）の熱処理を表 1 に示す。ここで, 質別記号 T は熱処理を示し，以下の処理状態に対応する。

$\mathrm{T} 4$ ：溶体化処理後，自然時効した状態。

T5：高温の製造工程から冷却後，人工時効した状態。

$\mathrm{T} 6$ ：溶体化処理後，人工時効した状態（T61 処理は $\mathrm{T} 6$ 処 理をさらに調整した状態）。

これらの熱処理過程を図 1 に模式的に示す。なお，F 材は 製造のままのものを示す。さらに，各種実用合金の具体的な 熱処理条件（溶体化処理条件，時効処理条件）を表 2 に示 す。

(1) 溶体化処理

合金元素の偏析を解消し，溶質元素の十分な固溶を確保す るために行う。溶体化温度は共晶温度直下の温度とするのが よい。溶体化温度が高くなると共晶融解などがおこり，膨れ やボイドが発生するため注意が必要である。溶体化温度まで の昇温はゆっくりとし，過熱による部分溶解などがおこらな いように注意する。昇温時間は製品の大きさや肉厚，合金成 分などを考慮して決める。また，溶体化時間としては，非平 衡相の溶解や偏析の解消に必要な時間とする。鋳造組織が微 細であれば，短時間で所定の均一組織が得られるため，有利
表 1 各種マグネシウム合金の熱処理

\begin{tabular}{|c|c|c|c|c|}
\hline 合金名 & \multicolumn{4}{|c|}{ 熱処理 } \\
\hline $\begin{array}{c}\text { 鋳造合金 } \\
\text { AM100A } \\
\text { AZ63A } \\
\text { AZ81A } \\
\text { AZ91C } \\
\text { AZ92A } \\
\text { EZ33A } \\
\text { EQ21A } \\
\text { QE22A } \\
\text { WE43A } \\
\text { WE54A } \\
\text { ZC63A } \\
\text { ZE41A } \\
\text { ZE63A } \\
\text { ZK51A } \\
\text { ZK61A }\end{array}$ & $\begin{array}{l}\mathrm{T} 4 \\
\mathrm{~T} 4 \\
\mathrm{~T} 4 \\
\mathrm{~T} 4 \\
\mathrm{~T} 4\end{array}$ & $\begin{array}{l}\mathrm{T} 5 \\
\mathrm{~T} 5\end{array}$ & $\begin{array}{l}\mathrm{T} 6 \\
\mathrm{~T} 6 \\
\mathrm{~T} 6 \\
\mathrm{~T} 6 \\
\mathrm{~T} 6 \\
\mathrm{~T} 6 \\
\mathrm{~T} 6 \\
\mathrm{~T} 6 \\
\mathrm{~T} 6 \\
\mathrm{~T} 6 \\
\mathrm{~T} 6\end{array}$ & $\mathrm{~T} 61$ \\
\hline $\begin{array}{c}\text { 押出合金 } \\
\text { AZ80A } \\
\text { ZC71A } \\
\text { ZK60A }\end{array}$ & & $\begin{array}{l}\text { T5 } \\
\text { T5 } \\
\text { T5 }\end{array}$ & T6 & \\
\hline
\end{tabular}

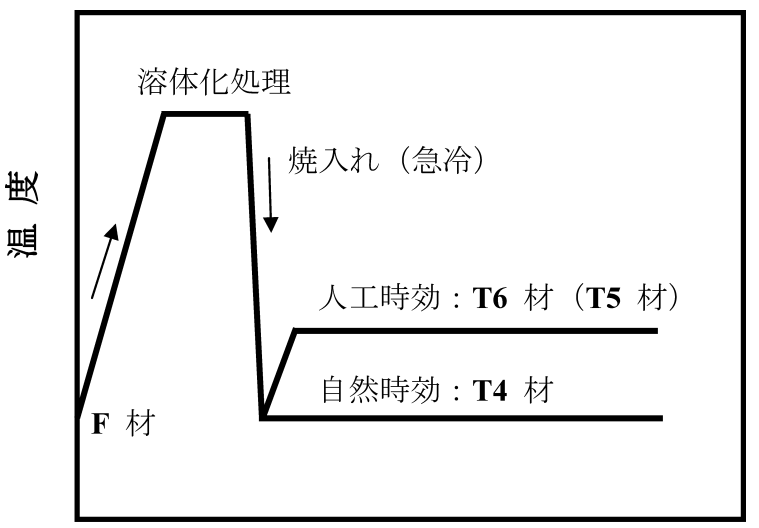

時 効 時 間

図 1 代表的な熱処理過程と質別記号

\footnotetext{
*東京工業大学大学院理工学研究科（广 152-8552 東京都目黒区大岡山 2-12-1, S8-13）。Department of Metallurgy and Ceramics Science, Tokyo Institute of Technology (2-12-1-S8-13, O-okayama, Meguro-ku, Tokyo 152-8552).E-mail: sato@mtl.titech.ac.jp
} 受付日：平成 22 年 1 月 14 日 受理日：平成 22 年 2 月 3 日 


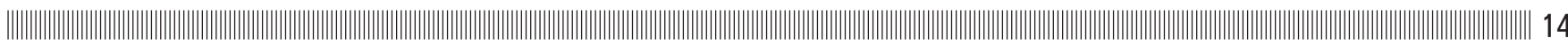

表 2 各種マグネシウム合金の熱処理温度および時間

\begin{tabular}{|c|c|c|c|c|c|}
\hline \multirow{3}{*}{ 合金名 } & \multicolumn{5}{|c|}{ 熱処理 } \\
\hline & \multirow{2}{*}{ 調質 } & \multicolumn{2}{|c|}{ 溶体化処理 } & \multicolumn{2}{|c|}{ 時効処理 } \\
\hline & & $\begin{array}{c}\text { 温度 } \\
\left({ }^{\circ} \mathrm{C}\right)\end{array}$ & $\begin{array}{c}\text { 時間 } \\
\text { (h) }\end{array}$ & $\begin{array}{l}\text { 温度 } \\
\left({ }^{\circ} \mathrm{C}\right)\end{array}$ & $\begin{array}{c}\text { 時間 } \\
\text { (h) }\end{array}$ \\
\hline $\begin{array}{r}\text { 鋳造合金 } \\
\mathrm{AM} 100 \mathrm{~A}\end{array}$ & $\begin{array}{l}\mathrm{T} 4 \\
\mathrm{~T} 6 \\
\mathrm{~T} 61 \\
\mathrm{~T} 5\end{array}$ & 424 & $16-24$ & $\begin{array}{l}232 \\
218 \\
232\end{array}$ & $\begin{array}{r}5 \\
25 \\
5\end{array}$ \\
\hline AZ63A & $\begin{array}{l}\text { T4 } \\
\text { T6 } \\
\text { T5 }\end{array}$ & 385 & $10-14$ & $\begin{array}{l}218 \\
260\end{array}$ & $\begin{array}{l}5 \\
4\end{array}$ \\
\hline AZ81A & $\mathrm{T} 4$ & 413 & $16-24$ & & \\
\hline AZ91C & $\begin{array}{l}\mathrm{T} 4 \\
\mathrm{~T} 6 \\
\mathrm{~T} 5\end{array}$ & 413 & $16-24$ & $\begin{array}{l}168 \\
168\end{array}$ & $\begin{array}{l}16 \\
16\end{array}$ \\
\hline AZ92A & $\begin{array}{l}\mathrm{T} 4 \\
\mathrm{~T} 6 \\
\mathrm{~T} 5\end{array}$ & 407 & $16-24$ & $\begin{array}{l}218 \\
260\end{array}$ & $\begin{array}{l}5 \\
4\end{array}$ \\
\hline EZ33A & $\mathrm{T} 5$ & & & 175 & 16 \\
\hline EQ21A & $\mathrm{T} 6$ & 520 & $4-8$ & 200 & 16 \\
\hline QE22A & $\mathrm{T} 6$ & 525 & $4-8$ & 204 & 8 \\
\hline WE43A & $\mathrm{T} 6$ & 525 & $4-8$ & 250 & 16 \\
\hline WE54A & $\mathrm{T} 6$ & 527 & $4-8$ & 250 & 16 \\
\hline ZC63A & $\mathrm{T} 6$ & 440 & $4-8$ & 200 & 16 \\
\hline ZE41A & $\mathrm{T} 5$ & & & 329 & 2 \\
\hline ZE63A & $\mathrm{T} 6$ & 480 & $10-72$ & 141 & 48 \\
\hline ZK51A & $\mathrm{T} 5$ & & & 177 & 12 \\
\hline ZK61A & $\begin{array}{l}\text { T6 } \\
\text { T5 }\end{array}$ & 499 & 2 & $\begin{array}{l}129 \\
149\end{array}$ & $\begin{array}{l}48 \\
48\end{array}$ \\
\hline $\begin{array}{c}\text { 押出合金 } \\
\text { AZ80A }\end{array}$ & $\mathrm{T} 5$ & & & 177 & $16-24$ \\
\hline ZC71A & $\begin{array}{l}\mathrm{T} 6 \\
\mathrm{~T} 5\end{array}$ & 430 & $4-8$ & $\begin{array}{l}180 \\
180\end{array}$ & $\begin{array}{l}16 \\
16\end{array}$ \\
\hline ZK60A & $\mathrm{T} 5$ & & & 150 & 24 \\
\hline
\end{tabular}

である。溶体化処理炉の温度ならびに酸化防止の雾囲気には 十分に注意する。マグネシウムは $400^{\circ} \mathrm{C}$ 以上の高い温度で長 時間保持すると酸化が進行し，場合によっては発火すること あある。そのため, 酸化防止の雾囲気が必要である。また,
表 3 各種展伸用マグネシウム合金の焼なまし温度

\begin{tabular}{l|c}
\hline \hline 合金名 & 焼なまし温度 $\left({ }^{\circ} \mathrm{C}\right)$ \\
\hline AZ31B, C & 345 \\
AZ61A & 345 \\
AZ80A & 385 \\
ZK60A & 290 \\
\hline
\end{tabular}

表 4 各種展伸用マグネシウム合金の残留応力除去熱処理

\begin{tabular}{l|c|c}
\hline \multirow{2}{*}{ 合金名 } & \multicolumn{2}{|c}{ 熱処理 } \\
\cline { 2 - 3 } & 温度 $\left({ }^{\circ} \mathrm{C}\right)$ & 時間 (min) \\
\hline 板材 & & \\
AZ31B-O & 345 & 120 \\
AZ31B-H24 & 150 & 60 \\
\hline 押出材 & & \\
AZ31B-F & 260 & 15 \\
AZ61A-F & 260 & 15 \\
AZ80A-F & 260 & 15 \\
AZ80A-T5 & 200 & 60 \\
ZC71A-T5 & 330 & 60 \\
ZK21A-F & 200 & 60 \\
ZK60A-F & 260 & 15 \\
ZK60A-T5 & 150 & 60 \\
\hline
\end{tabular}

熱処理炉などの温度ができるだけ一様になるように工夫する。 （2）焼入れ

マグネシウム合金製品は, 通常, 大気中で冷却が行われ る。製品の肉厚が厚いときには強制空冷が必要となる。また, 場合によっては，60 95 ${ }^{\circ} \mathrm{C}$ の水に焼入れたり，油焼入れをす る。なお，焼入れによりひずみ等の発生がないように工夫す る必要がある。

(3) 時効析出処理

過飽和固溶体から種々の析出をおこさせる目的で時効処理 を施す。合金系や時効温度に依存して様々な相の析出現象が おこる。析出には各相の TTT 曲線 (C 曲線) に析出がもっ とも早くおこるノーズ温度がある。この温度を目安に時効温 度を決めるとよい。

（4）焼なまし処理および残留応力除去熱処理

ここで，参考までに各種実用マグネシウム合金の焼なまし 処理および残留応力除去熱処理の条件について, それぞれ表 3 および表 4 に示す。残留応力除去に要する時間む表の中に 規定されている。

\section{2 時効析出の基礎}

合金の過飽和固溶体から新しく別の固相（固溶体，金属間 化合物相など）が形成される現象を析出とよんでいる。析出 は溶質原子の固体内拡散によっておこる拡散相変態であり, 基本的には状態図ならびにギブズエネルギーをもとに理解さ れる。ここで, 析出の形態的特徵をもとに均一固溶体から析 出が進行する過程をまとめると図 2 のようになる。すなわち, 


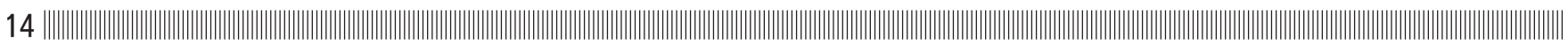

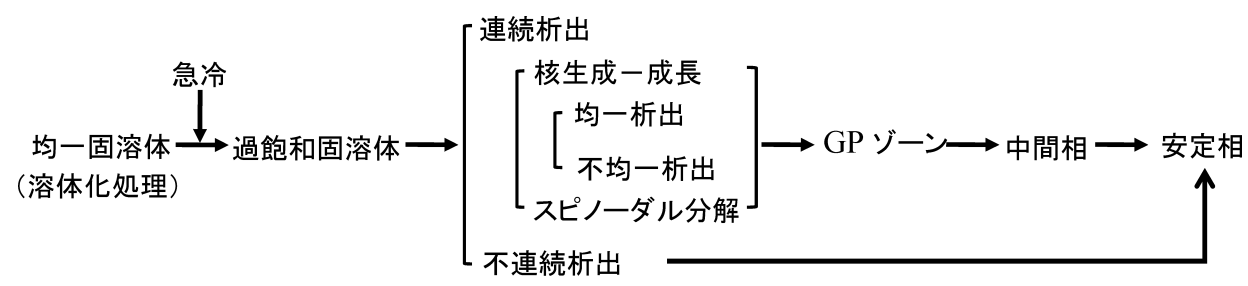

図 2 均一固溶体加らの各種析出の進行過程

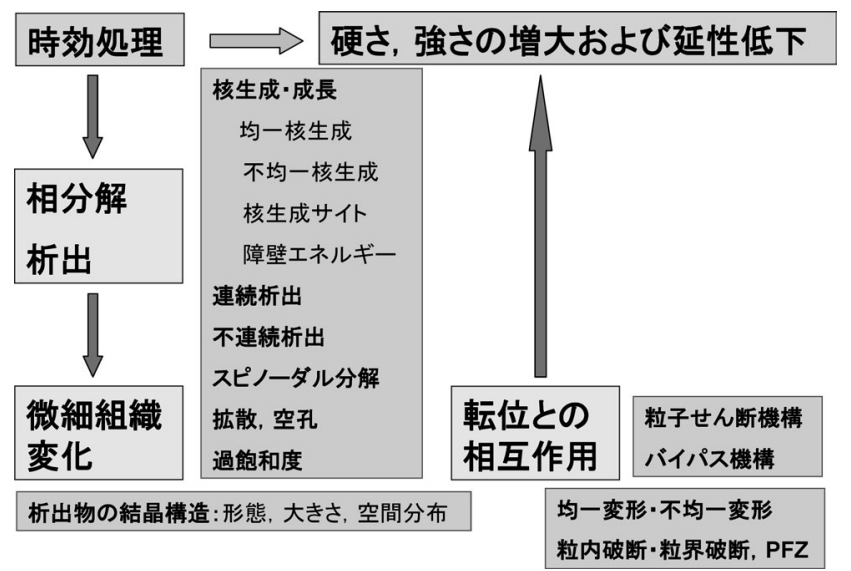

図 3 時効硬化現象と各種組織因子との関係

過飽和固溶体から連続析出あるいは不連続析出により析出が 進行する。また，連続析出には核生成一成長過程やスピノー ダル分解過程があり，また，合金系によっては GP ン゙ーンや 中間相を経て安定相に至る。

通常, 時効処理により, 合金の硬さや強さは増大し, 延性 は逆に低下する傾向にある。これらは時効析出現象ならびに 析出相之転位との相互作用の関係に依存して種々变化する。 これらの特性に関係する諸因子を図 3 にまとめて示す。

(1) 連続析出

連続析出は結晶粒内に均一または不均一に析出がおこり, 結晶粒内で次第に成長する場合であり, 母相濃度は連続的に 減少する。また，濃度ゆらぎが連続的に発達して相分解する スピノーダル分解あある。均一核生成とは, 過飽和固溶体中 で溶質原子濃度の熱的ゆらぎによって新しい相が空間的にラ ンダムに形成される場合であり，不均一核生成とは，格子欠 陷, 結晶粒界, 介在物, 界面などで核生成がおこる場合をい う。また，スピノーダル分解では濃度ゆらぎが急速に発達し て相分解する。このとき, 核生成のときのような障壁エネル ギーは存在せず，原子の拡散により自発的に分解が進行する。

(2) 不連続析出

不連続析出では結晶粒界上や粒界近傍で優先的に析出が抒 こり, 次第に粒内に向かって成長するあのであり, 析出の前 後で母相濃度は不連続的に減少する。不連続析出では特徵と してパーライト状のノジュールが形成されるためノジュラー 析出あるいはセル状析出などともよばれる。実際の観察では 不連続析出がある程度進行した後で, 連続析出がおこる場合 が多い。

ノジュールの成長は粒界拡散と粒界の移動度に律速されて
いる。また，ノジュールの層間隔は合金組成，時効温度など に依存して变化する。同一合金では, 濃度が高いものほど, また，時効温度が低いものほど層間隔が微細になる。また， 時効が進行してはじめのノジュール（一次ノジュール）が全 面を覆うと, より層間隔の広い二次ノジュールが発達する。

(3) 析出反応速度

析出の反応率（析出量の割合）の時間依存性は一般に Johnson-Mehl-Avrami の式 1),2) によって記述される場合が多 い。すなわち, 析出の反応率を $f(0 \leqq f \leqq 1)$, 時間を $t$ とする 々,

$$
f=1-\exp \left(-K t^{n}\right)
$$

で与えられる。 $n$ は時間指数で $1 \sim 4$ 程度の範囲で变化する。 また, $K$ は温度に依存する速度定数であり, 活性化ェネル ギーを含んでいる。この関係を利用して, 析出反応の時間指 数掞よび活性化エネルギーを実験的に求めることができる。

\section{3 各種マグネシウム合金の時効挙動}

合金の固溶度が温度の低下とともに減少する場合は過飽和 状態を解消するため時効析出が沶こる。時効析出過程や析出 組織は合金系や時効温度, また, 添加元素の有無などによっ て変化する。マグネシウム合金の時効析出過程は複雑な場合 が多く, 十分には解明されていない。以下に代表的なマグネ シウム合金の時効析出過程を述べる。

(1) $\mathrm{Mg}-\mathrm{Al}$ 系合金

$\mathrm{Mg}-\mathrm{Al}$ 二元合金の析出過程は,

$$
\alpha \rightarrow \beta\left(\mathrm{Mg}_{17} \mathrm{Al}_{12}\right)
$$

であり, GP ゾーンや中間相などの準安定相は形成されず, 直 接安定相が析出する。 $\beta$ 相の結晶構造は bccであり, 結晶粒 内に析出する連続析出之粒界反応型の不連続析出とにより形 成される。それぞれの析出組織を図 4 に示す ${ }^{3)}$ 。 $\beta$ 相は $\alpha-\mathrm{Mg}$ 母相の底面にラス状に析出し, 不連続析出はノジュ ラー組織（またはセル状組織）を形成する。母相との方位関 係は，連続析出では主として， $[111]_{\beta} / /[2 \overline{1} \overline{1} 0]_{\mathrm{Mg}}, \quad[0 \overline{1} 1]_{\beta} / /$ $[0001]_{\mathrm{Mg}}$ であり, 一部, $[2 \overline{1} 1]_{\beta} / /[2 \overline{1} \overline{1} 0]_{\mathrm{Mg}}, \quad[11 \overline{1}]_{\beta} / /[0001]_{\mathrm{Mg}}$ の方位関係も存在するとされる ${ }^{4)}$ 。一方, 不連続析出は連続 析出での主要な方位関係之類似の方位関係をむつものと, そ れ以外のもの之が存在することが報告されている ${ }^{4)}$ 。 $\mathrm{Mg} に$ $\mathrm{Al}$ を固溶させると格子ひずみが発生し, 大きな固溶硬化が得 られる。また，時効析出により顕著に時効硬化する。図 5 (a) に $\mathrm{Mg}-9 \% \mathrm{Al}$ 合金の時効硬化曲線を示す ${ }^{3)}$ 。これは連続析出 および不連続析出を含む平均硬さを示したものであり，おお むね $\mathrm{S}$ 字型の硬化となる。不連続析出領域のみの硬さを図 


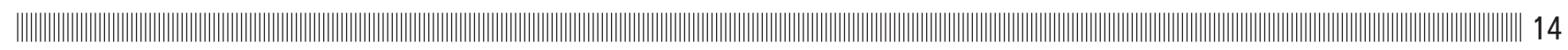

(a)

(b)
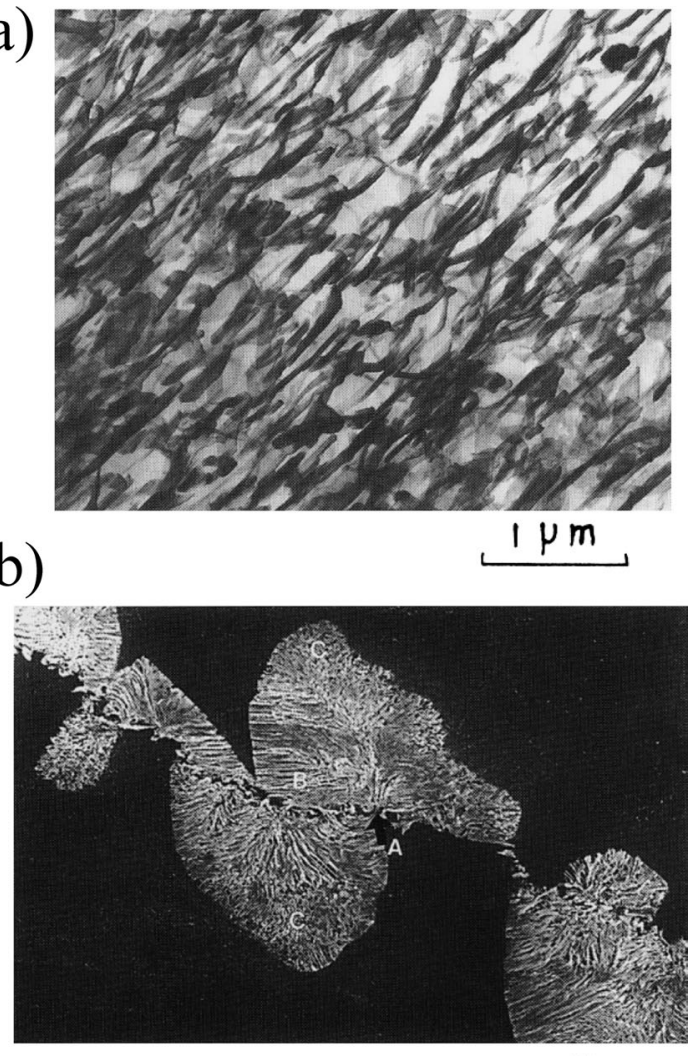

$1 \mathrm{OPm}$

図 $4 \mathrm{Mg}-9 \% \mathrm{Al}$ 合金の（a）連続析出組織（ $\left(170^{\circ} \mathrm{C}, 20 \mathrm{~h}\right)$ 之 (b) 不連続析出組織 $\left(170^{\circ} \mathrm{C}, 20 \mathrm{~h}\right)^{3)}$

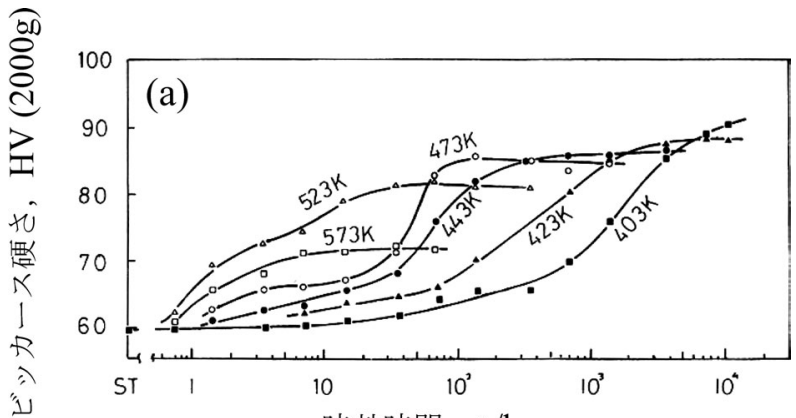

時効時閒, $t / \mathrm{ks}$

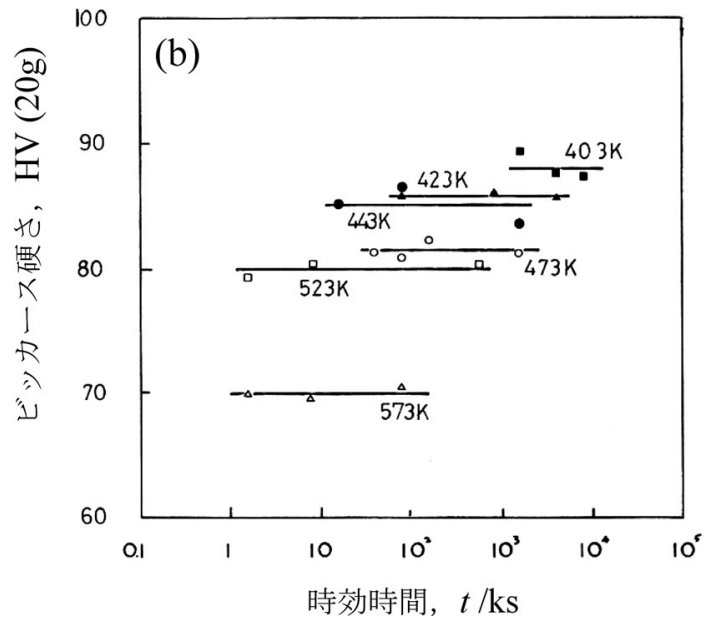

図 5 （a） $\mathrm{Mg}-9 \% \mathrm{Al}$ 合金の時効硬化曲線打よび（b）， ジュール領域の硬さ ${ }^{3)}$

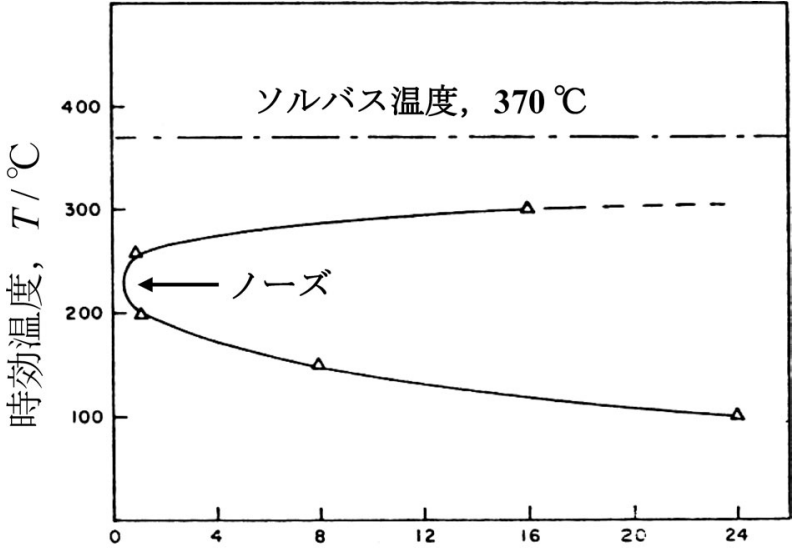

時効時間, $t / \mathrm{h}$

図 $6 \mathrm{Mg}-9 \% \mathrm{Al}$ 合金の析出 $\mathrm{C}$ 曲線 ${ }^{5)}$

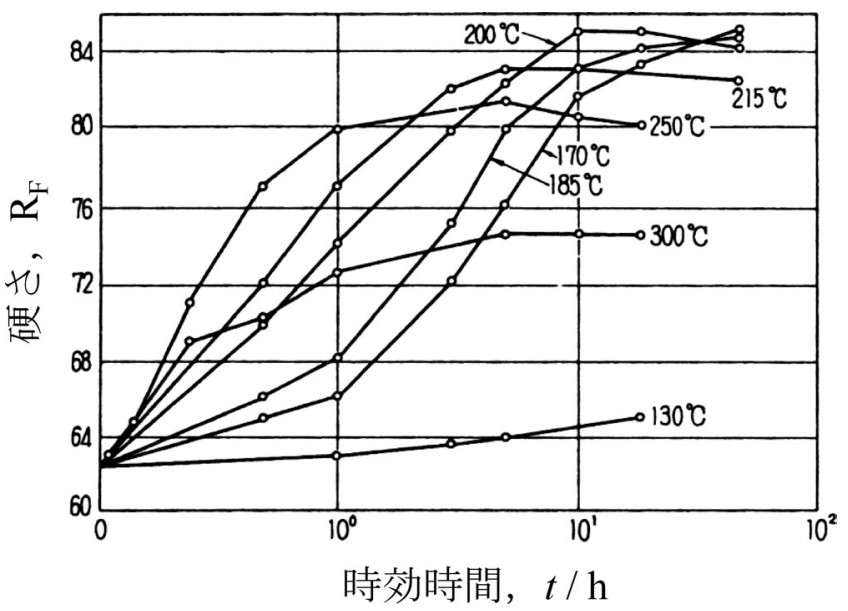

図 $7 \quad \mathrm{Mg}-9 \% \mathrm{Al}-1 \% \mathrm{Zn}(\mathrm{AZ} 91)$ 合金の時効硬化曲線 $\left.{ }^{6}\right)$
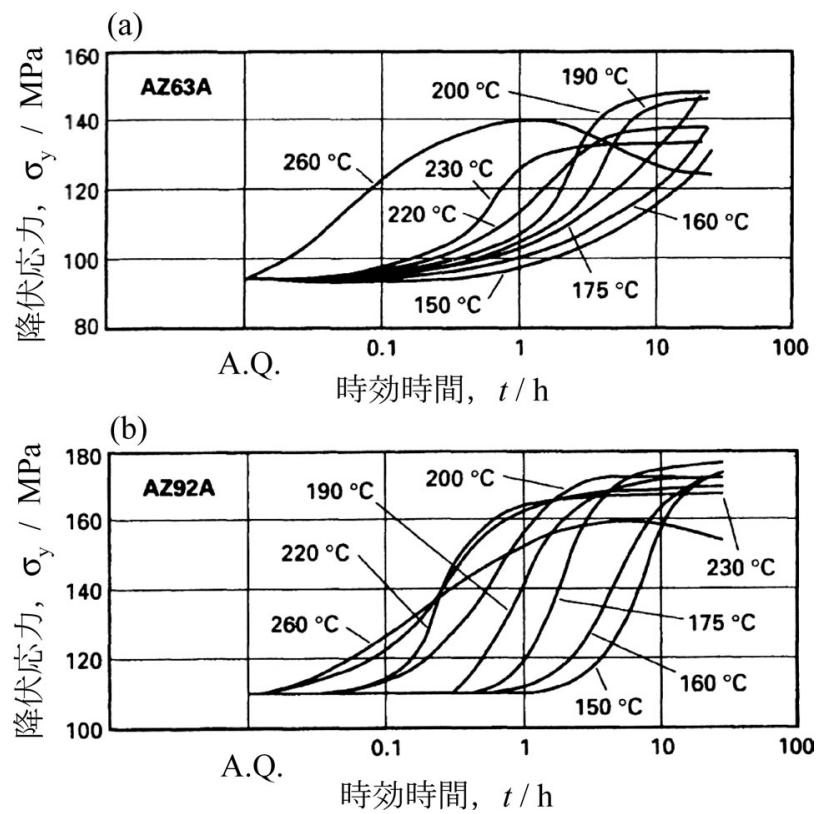

図 8 (a) AZ63A および（b）AZ92A 合金の各温度におけ る時効硬化曲線 ${ }^{7)}$ 
14

5 (b) に示す 3)。不連続析出は時効の比較的初期から抢こる が，時効の進行とともに連続析出も生じ，両者は競合する。 また，両析出形態は常に共存するのではなく，組成㧍よび時 効温度によって異なる。図 6 亿析出の C曲線を示す5)。ノー ズ温度はほぼ $230^{\circ} \mathrm{C}$ であり, 図 5 の時効硬化曲線で $523 \mathrm{~K}$ $\left(250^{\circ} \mathrm{C}\right)$ で最む速く時効硬化することと対応する。

$\mathrm{Mg}-\mathrm{Al}-\mathrm{Zn}$ 合金（AZ91 合金）の時効硬化曲線の例を図 7 に示す $)^{6}$ 。この合金でも $\mathrm{Zn}$ 含有量は $\mathrm{Al}$ より少なく, 基本的 な析出過程は $\mathrm{Mg}-\mathrm{Al}$ 二元合金と同一である。しかしながら， $\mathrm{Mg}-\mathrm{Al}-\mathrm{Zn}$ 合金では $\mathrm{Mg}-\mathrm{Al}$ 合金に比べ，時効が促進され，ま た，強度むある程度増大する。さらに，AZ92 合金㧍よび AZ63 合金の種々の温度での時効硬化曲線を図 8 に示す 7)。 また, $\mathrm{Cu}$ を微量添加すると時効硬化が促進される。これは, $\mathrm{Cu}$ が $\beta$ 相 $\mathrm{Mg}_{17} \mathrm{Al}_{12}$ の核生成を促進するためと考えられてい る。 $\mathrm{Mg}-\mathrm{Al}$ 合金に $\mathrm{Ca}$ あるいは $\mathrm{Si}$ を添加するとクリープ強度 が増大する。これは, $\mathrm{Mg}_{2} \mathrm{Ca} や \mathrm{Mg}_{2} \mathrm{Si}$ の析出によるあのであ る。また, RE 元素 (希土類元素) を添加すると, 比較的安 定な組織が得られ，クリープ強度が増大する。

(2) $\mathrm{Mg}-\mathrm{Zn}$ 系合金

$\mathrm{Mg}-\mathrm{Zn}$ 二元合金の析出過程は,

$$
\alpha \rightarrow \mathrm{GP} \text { ゾーン } \rightarrow \beta_{1}{ }^{\prime} \rightarrow \beta_{2}{ }^{\prime} \rightarrow \beta
$$

となることが知られている。ここで，

$\mathrm{GP}$ ゾーン：板状 (整合), $\{0001\}_{\mathrm{Mg}}$ 面上に析出,

$\beta_{1}^{\prime}\left(\mathrm{MgZn}_{2}\right)$ : 棒状 (整合), $\{0001\}_{\mathrm{Mg}}$ 面上に垂直,

六方晶 $(\mathrm{a}=0.52 \mathrm{~nm}, \mathrm{c}=0.85 \mathrm{~nm})$

$\beta_{2}^{\prime}\left(\mathrm{MgZn}_{2}\right)$ : 板状 (半整合), $\{0001\}_{\mathrm{Mg}}$ 面上に析出,

$$
(11 \overline{2} 0)_{\beta_{2}^{\prime}} / /(10 \overline{1} 0)_{\mathrm{Mg}}
$$

六方晶 $(\mathrm{a}=0.52 \mathrm{~nm}, \mathrm{c}=0.848 \mathrm{~nm})$

$\beta\left(\mathrm{Mg}_{2} \mathrm{Zn}_{3}\right)$ : 三方晶系（非整合）

$\left(\mathrm{a}=1.724 \mathrm{~nm}, \mathrm{~b}=1.445 \mathrm{~nm}, \mathrm{c}=0.52 \mathrm{~nm}, \gamma=138^{\circ}\right)$ である。

このように, Mg-Zn 合金の析出過程は複雑であり，4段階 の過程があると考えられている。強度が最大となるのは $\beta_{1}^{\prime}$ 相の段階である。また，低温で予備時効を行い，GPゾーン を形成させてから高い温度で時効すると $\beta_{1}{ }^{\prime}$ 相は微細となる。 図 9 に $\mathrm{Mg}-4 \% \mathrm{Zn}$ 合金の時効硬化曲線を示す ${ }^{8)}$ 。 $\beta_{1}^{\prime}$ は棒状を しており, 析出相周囲の界面に整合ひずみが存在し, 析出強 化に有効である。Mg-Zn 合金に希土類元素を微量添加すると

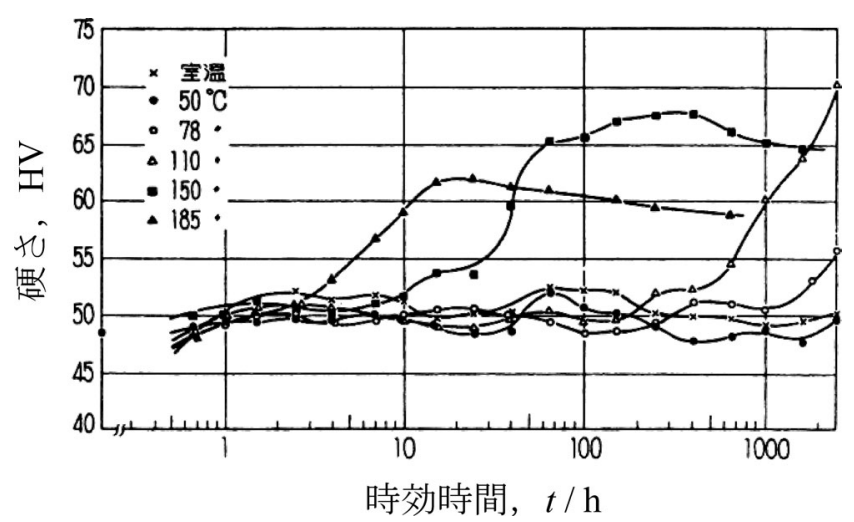

図 $9 \mathrm{Mg}-4 \% \mathrm{Zn}$ 合金の時効硬化曲線 ${ }^{8)}$ $\beta_{2}^{\prime}$ 相の析出が抑制され, 過時効が遅くなる。また, $\mathrm{Cu}$ を添 加すると時效硬化が増大し, また, 高温強度む高くなる。こ れは $\mathrm{Cu}$ 添加により, $\beta_{1}^{\prime}$ 相や $\beta_{2}^{\prime}$ 相の析出密度が増大するこ とによる。ZC63 合金やZCM630 合金などが害用合金としてあ る。

$\mathrm{Mg}-\mathrm{Zn}$ 合金に $\mathrm{Ag}$ や $\mathrm{Ca}$ を微量添加すると時効硬化が促進 され，また，硬さす増大する。図 10 に $\mathrm{Mg}-\mathrm{Zn}$ 合金に $\mathrm{Ag}$ や Ca を添加した合金の時効硬化曲線を示す 9)。Ag 添加により 時効硬化が増大し, さらに, Ca 添加により一層の硬さ増加 が認められる。図 11 および図 12 に Mg-Zn 合金および Ca 添

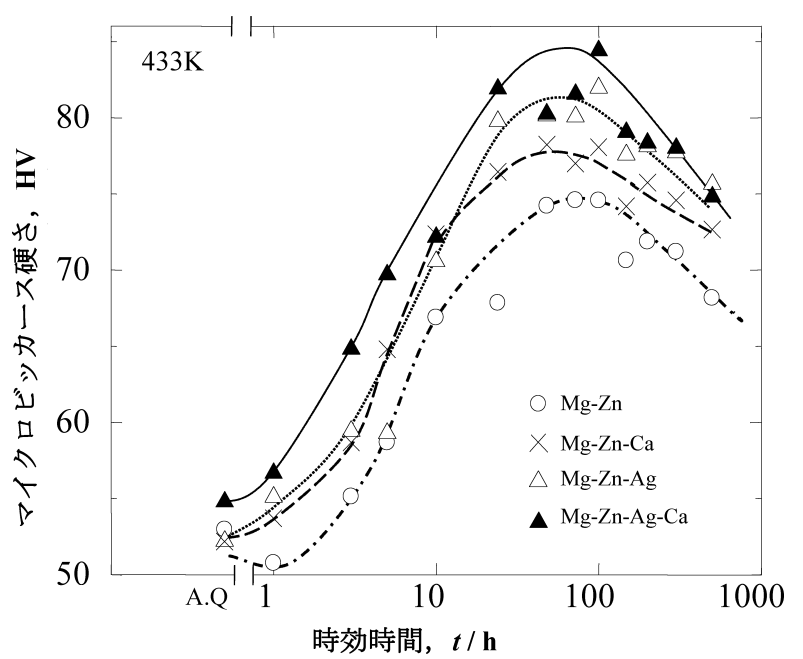

図 $10 \mathrm{Mg}-6 \% \mathrm{Zn}$ 合金および $0.6 \% \mathrm{Ag}$ および $0.6 \% \mathrm{Ca}$ を単 独あるいは複合添加した合金の $160^{\circ} \mathrm{C}$ での時効硬化曲 線 9 )
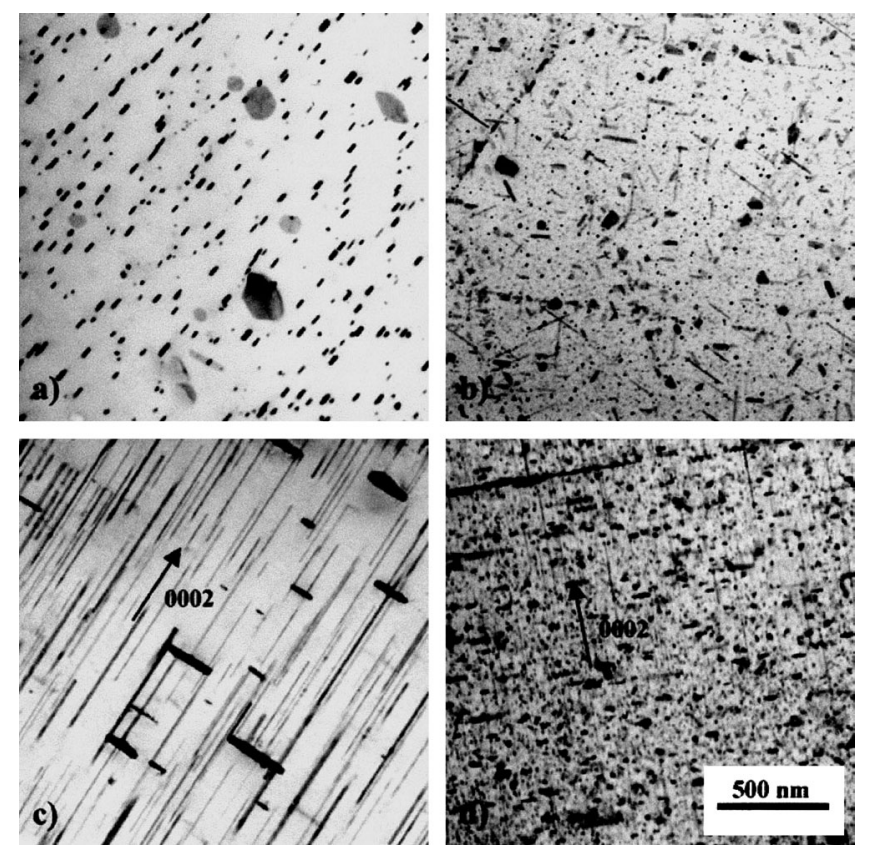

図 $11 \mathrm{Mg}-4 \% \mathrm{Zn}$ 合金（a,c）打よび $\mathrm{Mg}-4 \% \mathrm{Zn}(\mathrm{Zr})-$ $0.35 \% \mathrm{Ca}$ 合金（b, d）を $177^{\circ} \mathrm{C}$ で約 $10^{4} \mathrm{ks}$ 時効したとき の電顕組織 ${ }^{10)}$ 。写真 $\mathrm{a}, \mathrm{b}$ は母相の [0001］に平行に, 写真 c, d は母相の [1120]］に平行に撮影 

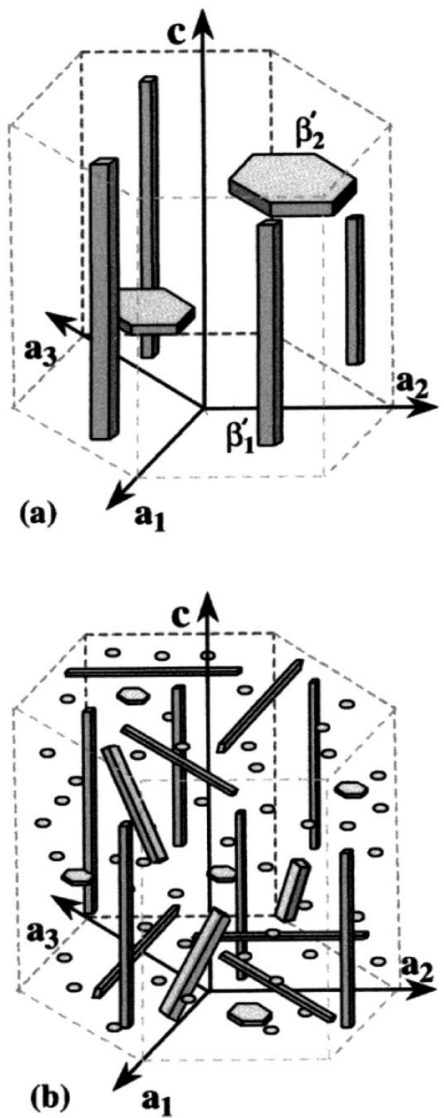

図 $12 \mathrm{Mg}-\mathrm{Zn}$ 合金に形成される析出組織（過時効状態） の形態（母相との関係で示す）

(a) $\mathrm{Mg}-4 \% \mathrm{Zn}$ 合金, (b) $\mathrm{Mg}-4 \% \mathrm{Zn}-0.35 \% \mathrm{Ca}$ 合金 ${ }^{10)}$

加合金の析出組織ならびに析出形態の模式図を示す ${ }^{10)}$ 。棒状 の $\beta_{1}{ }^{\prime}$ 相抢よび板状の $\beta_{2}^{\prime}$ 相が形成され，Ca，Ag などの添加 により析出相は微細となる。Caや $\mathrm{Ag}$ は析出相内に含まれる ことが明らかにされており (図 13) ${ }^{9)}$ ，核生成・成長に直接 影響を及ぼすことが示唆される。

一方，押出，圧延による加工と熱処理との組合せによる析 出挙動が検討されている。加工による結晶粒の微細化之時効 時の析出の促進が期待される。加工は, $300 \sim 400^{\circ} \mathrm{C}$ で行われ， 動的再結晶により結晶粒が微細化する。さらに, 加工後, $200^{\circ} \mathrm{C}$ で時効すると, 粒界での不連続析出が著しく減少し, 粒内の析出物は微細化することが報告されている。

(3) $\mathrm{Mg}-\mathrm{Mn}$ 系合金

$\mathrm{Mg}-\mathrm{Mn}$ 合金では時効硬化はきわめてわずかである。析出 過程は,

$$
\alpha \rightarrow \alpha-\mathrm{Mn} \text { (立方晶) }
$$

であり，準安定相は認められていない。 $\alpha-M n$ 相は棒状であ り，棒は $[0001]_{\mathrm{Mg}}$ および $[2 \overline{1} \overline{1} 0]_{\mathrm{Mg}}$ 方向に平行であり, $\mathrm{Mg}$ 母相之は次の 2 つの方位関係があることが報告されている ${ }^{11) 。 ~}$
(1) $\{111\}_{\mathrm{Mn}} / /\{0001\}_{\mathrm{Mg}}$
(2) $\{111\}_{\mathrm{Mn}} / /\{1120\}_{\mathrm{Mg}}$
$\{1 \overline{1} 0\}_{\mathrm{Mn}} / /\{10 \overline{1} 0\}_{\mathrm{Mg}}$
$\{1 \overline{1} 0\}_{\mathrm{Mn}} / /\{0001\}_{\mathrm{Mg}}$

また，析出物は主として転位線上に析出する。 Mn は通常, 単独では添加されず， $\mathrm{Al}$ などとともに添加される。したがっ
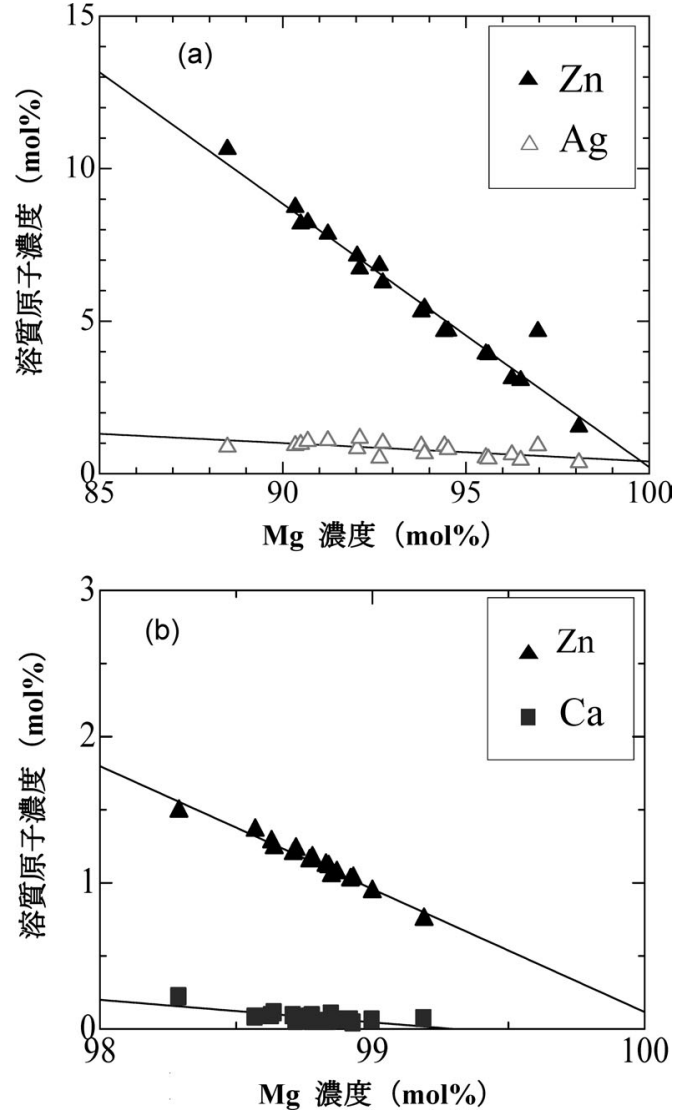

図 $13 \mathrm{Mg}-\mathrm{Zn}$ 合金に $\mathrm{Ag}$ あるいは $\mathrm{Ca}$ を微量添加した合 金の析出相の EDS 分析結果。Cliff-Lorimer プロットに より，直線の勾配が負であることがわかり， $\mathrm{Ag}, \mathrm{Ca}$ が析出相に含まれることがわかる ${ }^{9)}$

(a) $\mathrm{Mg}-\mathrm{Zn}-\mathrm{Ag}$ 合金, (b) $\mathrm{Mg}-\mathrm{Zn}-\mathrm{Ca}$ 合金

て, $\mathrm{Al}$ が同時に添加される場合には, $\mathrm{MnAl}, \mathrm{MnAl}_{6}, \mathrm{MnAl}_{4}$ などの化合物が形成される。

(4) $\mathrm{Mg}-\mathrm{RE}$ 系合金

$\mathrm{Mg}-\mathrm{RE}$ 系合金では顕著な時効硬化を示す場合が多い。特 徵的なことは時効初期に六方晶の規則構造である $\mathrm{D} 0_{19}$ 型構造 $\left(\mathrm{Mg}_{3} \mathrm{Cd}\right.$ 型構造）が打打むね形成されることである。

(a) $\mathrm{Mg}-\mathrm{Y}$ 系合金

$\mathrm{Mg}-\mathrm{Y}$ 二元合金の時効析出過程は,

$$
\begin{aligned}
\alpha & \rightarrow \beta^{\prime \prime} \quad\left(\mathrm{D}_{19} \text { 型規則構造 }\right) \rightarrow \beta^{\prime} \text { 相（bco 構造） } \\
& \rightarrow \beta\left(\mathrm{Mg}_{24} \mathrm{Y}_{5} \text { : } \mathrm{bcc} \text { 構造 }\right)
\end{aligned}
$$

となっている。 $\beta^{\prime \prime}$ 相は母相の $\mathrm{Mg}$ が局所的に規則化すること により進展する。 $\beta^{\prime}$ 相は中間相であり, 初期は整合, 後期は 半整合となる。整合 $\beta^{\prime}$ 相の結晶構造は底心斜方晶であり, 母相とは, $[001]_{\beta^{\prime}} / /[0001]_{\mathrm{Mg}},(100)_{\beta^{\prime}} / /(\overline{2} 110)_{\mathrm{Mg}}$ となっている。 平衡相 $\beta$ は長時間時効したときに粒界上および粒内に析出す る。

(b) $\mathrm{Mg}-\mathrm{Y}-\mathrm{Nd}$ 合金

$\mathrm{Mg}-\mathrm{Y}$ 合金では時効初期にはあまり硬化せず，途中段階か ら急激に硬化するが，Nd を添加すると初期から硬化する。析 出過程は複雑であり, 


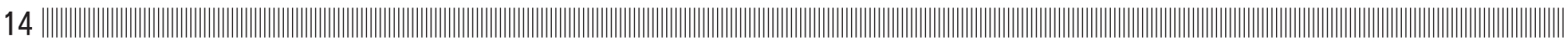
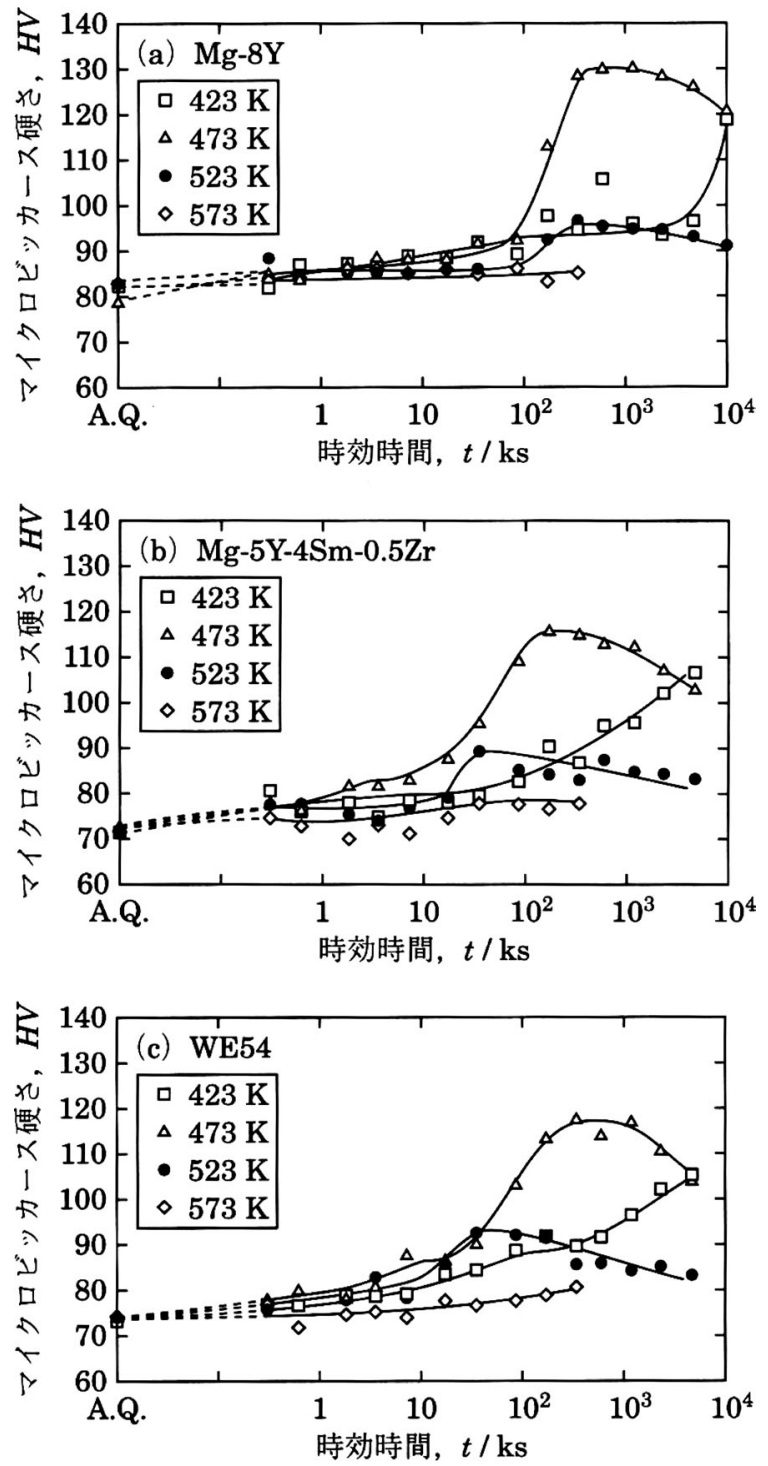

図 14 (a) $\mathrm{Mg}-8 \% \mathrm{Y}$ ，（b） $\mathrm{Mg}-5 \% \mathrm{Y}-4 \% \mathrm{Sm}-0.5 \% \mathrm{Zr}$ 打よ び (c) $\mathrm{Mg}-5 \% \mathrm{Y}-4 \% \mathrm{Nd}-0.5 \% \mathrm{Zr}$ (WE54) 合金の時効硬 化曲線 ${ }^{12)}$

$$
\begin{aligned}
\alpha & \rightarrow \beta^{\prime \prime}\left(\mathrm{D} 0_{19} \text { 型規則構造 }\right) \rightarrow \beta^{\prime} \text { 相 }(\mathrm{bco} \text { 構造 }) \\
& \rightarrow \beta(\mathrm{fcc} \text { 構造 })
\end{aligned}
$$

となる。ここで，

$\beta^{\prime \prime}$ 相 : $\mathrm{D} 0_{19}$ 型規則構造 $(a=0.64 \mathrm{~nm}, c=0.52 \mathrm{~nm})$ $(0001)_{\beta^{\prime \prime}} / /(0001)_{\mathrm{Mg}}, \quad[01 \overline{1} 0]_{\beta^{\prime \prime}} / /[01 \overline{1} 0]_{\mathrm{Mg}}$

$\beta^{\prime}$ 相: $\mathrm{Mg}_{12} \mathrm{NdY}$, 底心斜方晶（bco 構造） $[001]_{\beta^{\prime}} / /[0001]_{\mathrm{Mg}}, \quad(100)_{\beta^{\prime}} / /(2 \overline{1} \overline{1} 0)_{\mathrm{Mg}}$

$\beta$ 相 : $\mathrm{Mg}_{14} \mathrm{Nd}_{2} \mathrm{Y}$ ，面心立法晶 $(a=2.223 \mathrm{~nm})$ $[1 \overline{1} 1]_{\beta} / /[1 \overline{2} 10]_{\mathrm{Mg}},(011)_{\beta} / /(0001)_{\mathrm{Mg}}$

となる。 $\beta^{\prime \prime}$ および $\beta^{\prime}$ 相は基本的には $\mathrm{Mg}-\mathrm{Y}$ 合金と類似のも のであり, $\mathrm{Nd}$ は $\mathrm{Y}$ の一部を置換したものと考えられる。図 14 に $\mathrm{Mg}-8 \% \mathrm{Y}$ 合金, $\mathrm{Mg}-5 \% \mathrm{Y}-4 \% \mathrm{Sm}-0.5 \% \mathrm{Zr}$ 合金および $\mathrm{Mg}-5 \% \mathrm{Y}-4 \% \mathrm{Nd}-0.5 \% \mathrm{Zr}$ 合金の時効硬化曲線を示す ${ }^{12)}$ 。な お, $\mathrm{Mg}-\mathrm{Y}-\mathrm{Nd}-\mathrm{Zr}$ 合金は $300^{\circ} \mathrm{C}$ 程度までクリープ強度がすぐ れる。 $\mathrm{Mg}-\mathrm{Nd}$ 合金の時効過程も上記（6）に示される過程を 経ると考えられているが，詳細は必ずしも明らかではない。

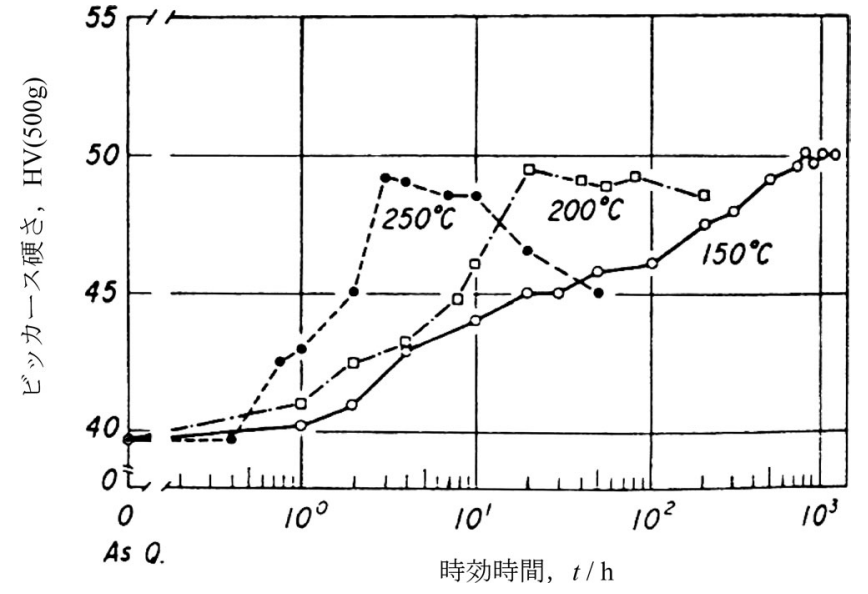

図 $15 \quad \mathrm{Mg}-1.3 \% \mathrm{Ce}$ 合金の時効硬化曲線 ${ }^{13)}$

(c) $\mathrm{Mg}-\mathrm{Ce}$ 合金

$\mathrm{Mg}-1.3 \% \mathrm{Ce}$ 合金の時効硬化曲線を図 15 に示す ${ }^{13)}$ 。また, 析出過程は,

$$
\alpha \rightarrow \text { 中間相 } \rightarrow \beta \text { 相 }\left(\mathrm{Mg}_{12} \mathrm{Ce}, \text { 六方晶 }\right)
$$

とされているが, 中間相の構造や変態過程については明らか とはなっていない。Zn を添加すると析出硬化は大きくなる。

(5) $\mathrm{Mg}-\mathrm{Th}$ 合金

Mg-Th 合金の時効析出過程は, 十分明らかにされていない が，次のように考えられている。

$$
\begin{aligned}
& \alpha \rightarrow \beta^{\prime \prime} \text { 相 }\left(\mathrm{D}_{19} \text { 型規則構造 }\right) \rightarrow \beta \text { 相 } \\
& \beta^{\prime \prime} \text { 相 : 円板状, }\{10 \overline{10}\}_{\mathrm{Mg}} \text { 面上 } \\
& \text { 六方晶（整合） } \\
& \beta \text { 相 : } \mathrm{Mg}_{23} \mathrm{Th}_{6} \\
& \text { fcc（非整合， } \mathrm{a}=1.43 \mathrm{~nm} \text { ) }
\end{aligned}
$$

このほかに， $\beta$ 相の前段階に半整合の $\beta_{1}^{\prime}$ 相（六方晶）あ るいは $\beta_{2}^{\prime}$ 相（fcc）の形成も考えられている ${ }^{14)}$ 。これらの析 出相は熱的安定性が高い。なお， $2 \% \mathrm{Th}$ を含む合金は放射性 を有するとされ, 特別な対応が求められるため, 使用は制限 される。

(6) $\mathrm{Mg}-\mathrm{Ca}, \mathrm{Mg}-\mathrm{Ca}-\mathrm{Zn}$ 合金

$\mathrm{Mg}-\mathrm{Ca}$ 合金の析出過程については十分には調べられていな い。安定相として $\mathrm{Mg}_{2} \mathrm{Ca}$ が析出する。 $\mathrm{Mg}_{2} \mathrm{Ca}$ は六方晶で $\mathrm{a}=0.623 \mathrm{~nm}, \mathrm{c}=1.012 \mathrm{~nm}$ となっている。 $\mathrm{Mg}-1 \% \mathrm{Ca}$ 合金に $1 \% \mathrm{Zn}$ を添加すると時効硬化が著しく増大する。 $\mathrm{Mg}-1 \% \mathrm{Ca}$ 合金では比較的粗大な析出物であるのに対して, $\mathrm{Mg}-1 \% \mathrm{Ca}-1 \% \mathrm{Zn}$ 合金では微細な析出物となっている。Zn 添 加の効果は明らかではないが，Zn が析出物中に含まれている あのと考えられる。なお， $\mathrm{Mg}-1 \% \mathrm{Ca}-1 \% \mathrm{Zn}$ 合金の鋳造材で は 2 種類の六方晶の板状化合物が認められている。格子定数 はそれぞれ，

$$
\begin{aligned}
& \mathrm{a}=0.623 \mathrm{~nm}, \quad c=1.012 \mathrm{~nm} \\
& \mathrm{a}=0.556 \mathrm{~nm}, \quad c=1.042 \mathrm{~nm}
\end{aligned}
$$




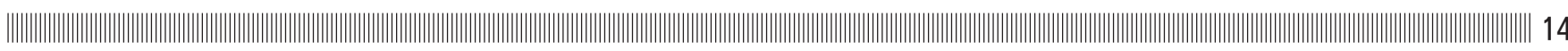

であり，母相との方位関係はいずれも

$$
(0001)_{\mathrm{p}} / /(0001)_{\mathrm{Mg}}, \quad[2 \overline{1} \overline{1} 0]_{\mathrm{p}} / /[10 \overline{1} 0]_{\mathrm{Mg}}
$$

となっている。

また, $\mathrm{Mg}-\mathrm{Al}$ 合金に $\mathrm{Ca}$ を添加すると高温強度が増大する。 特に, $\mathrm{Ca} / \mathrm{Al}$ 比が約 0.8 以上のとき, $\mathrm{Ca}$ 添加合金は著しく高 い硬さとなる。これは, $\mathrm{Mg}_{2} \mathrm{Ca}$ が析出し, この析出相が高温 強度に有効であるためと考えられる。

(7) $\mathrm{Mg}-\mathrm{Ag}-\mathrm{RE}(\mathrm{Nd})$

$\mathrm{Mg}-\mathrm{RE}(\mathrm{Nd})-\mathrm{Zr}$ 合金などに Ag を添加すると時効硬化性が 増大する。 $\mathrm{Ag}$ 濃度が $2 \%$ 以下では析出過程は $\mathrm{Mg}-\mathrm{RE}$ 合金と 同様であり, 一方, $\mathrm{Ag}$ 濃度が $2 \%$ 以上では, $\mathrm{Mg}_{12} \mathrm{Nd}_{2} \mathrm{Ag}$ が 析出する。 $\mathrm{Mg}-\mathrm{Ag}-\mathrm{RE}(\mathrm{Nd})$ 合金の析出過程は複雑であり, 十分には解明されていない。析出過程として, 次の過程が考 えられている。

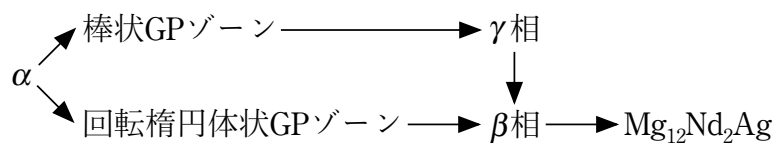

棒状 GP ゾーン：整合，（0001）面上に垂直

回転楕円体状 GP ゾーン : 整合, (0001) ${ }_{\mathrm{Mg}}$ 面に平行

$\gamma$ 相：棒状 (整合), 六方晶, $[0001]_{\mathrm{Mg}}$ に平行

$(\mathrm{a}=0.963 \mathrm{~nm}, \mathrm{c}=1.024 \mathrm{~nm})$

$\left(\mathrm{D} 0_{19}\right.$ 型構造の可能性あある。） $\beta$ 相：等軸状（半整合）

六方晶, $(0001)_{\beta} / /(0001)_{\mathrm{Mg}}$

$(11 \overline{2} 0)_{\beta} / /(10 \overline{1} 0)_{\mathrm{Mg}}$

$(\mathrm{a}=0.556 \mathrm{~nm}, \mathrm{c}=0.521 \mathrm{~nm})$

$\mathrm{Mg}_{12} \mathrm{Nd}_{2} \mathrm{Ag}$ : 複雑なラス状 (非整合), 六方晶

これらの各析出相で最高硬さが得られるのは $\gamma$ 相と $\beta$ 相の 共存のときである。 $\mathrm{Mg}-\mathrm{Ag}$ 系合金として, QE22 $(\mathrm{Mg}-2.5 \mathrm{Ag}-$ 2RE-0.7Zr）合金などがあり, 航空機用素材として活用されて いる。析出過程は Mg-RE 合金に類似している。

(8) $\mathrm{Mg}-\mathrm{Li}-\mathrm{Zn}$ 合金

$\mathrm{Li}$ 含有のため, さらに軽量の合金となる。 Li 含有合金は比 剛性および比強度に優れる。 $\mathrm{Al}, \mathrm{Zn}$ および RE を添加した合 金が検討され，これまで，LA141 合金や LS141 合金などが開 発されている。時効硬化特性については, 未解明の部分が多 い。

以上のように各種マグネシウム合金において，時効熱処理 を施すと様々な析出相が形成されることが示される。表 5 に 各種合金で形成される準安定相ならびに安定相についてまと める。

\section{3. 各種実用合金の熱処理および機械的性質}

各種実用マグネシウム合金を鋳物材および展伸材に分類し, 規格による引張強さ・降伏強さと伸びの関係を図 16 に示

表 5 各種マグネシウム合金の析出相およびそれらの結晶系

\begin{tabular}{|c|c|c|c|}
\hline 合金系 & 初期構造（GP ゾーンなど） & 中期構造（中間相） & 後期構造（安定相） \\
\hline $\mathrm{Mg}-\mathrm{Al}$ & - & - & $\begin{array}{l}\beta \text { 相 : } \mathrm{Mg}_{17} \mathrm{Al}_{12} \text { (立方晶) } \\
\text { 連続析出および不連続析出する }\end{array}$ \\
\hline $\mathrm{Mg}-\mathrm{Zn}$ & GP ゾーン：板状（整合） & $\begin{array}{l}\beta_{1}^{\prime} \text { 相: } \mathrm{MgZn}_{2} \text { (六方晶, 整合) } \\
\beta_{2}^{\prime} \text { 相: } \mathrm{MgZn}_{2} \text { (六方晶, 整合) }\end{array}$ & $\beta$ 相 : $\mathrm{Mg}_{2} \mathrm{Zn}_{3}$ (三方晶系, 非整合) \\
\hline $\mathrm{Mg}-\mathrm{Mn}$ & - & - & $\begin{array}{l}\alpha-\mathrm{Mn} \text { (立方晶) } \\
\text { 棒状 }\end{array}$ \\
\hline $\mathrm{Mg}-\mathrm{Y}$ & $\beta^{\prime \prime}$ 相 $: \mathrm{D} 0_{19}$ 型規則構造 & $\beta^{\prime}$ 相：底心斜方晶 & $\beta$ 相 $: \mathrm{Mg}_{24} \mathrm{Y}_{5}$ (体心立方晶) \\
\hline $\mathrm{Mg}-\mathrm{Nd}$ & $\begin{array}{l}\mathrm{GP} ソ ゙ ー ン ： \text { 棒状 (整合) } \\
\beta^{\prime \prime} \text { 相 }: \mathrm{D}_{19} \text { 型規則構造 }\end{array}$ & $\beta^{\prime}$ 相：面心立方晶 & $\beta$ 相 $: \mathrm{Mg}_{12} \mathrm{Nd}$ (体心正方晶) \\
\hline $\mathrm{Mg}-\mathrm{Y}-\mathrm{Nd}$ & $\beta^{\prime \prime}$ 相 $: \mathrm{D} 0_{19}$ 型規則構造 & $\beta^{\prime}$ 相 $: \mathrm{Mg}_{12} \mathrm{NdY}$ (底心斜方晶) & $\beta$ 相 : $\mathrm{Mg}_{14} \mathrm{Nd}_{2} \mathrm{Y}$ (面心立方晶) \\
\hline $\mathrm{Mg}-\mathrm{Ce}$ & - & 中間相（?） & $\beta$ 相: $\mathrm{Mg}_{12} \mathrm{Ce}$ (六方晶) \\
\hline $\mathrm{Mg}-\mathrm{Gd}, \mathrm{Mg}-\mathrm{Dy}$ & $\beta^{\prime \prime}$ 相 $: \mathrm{D} 0_{19}$ 型規則構造 & $\beta^{\prime}$ 相：斜方晶 & $\beta$ 相 : $\mathrm{Mg}_{24} \mathrm{Dy}_{5}$ （立方晶） \\
\hline $\mathrm{Mg}-\mathrm{Th}$ & $\beta^{\prime \prime}$ 相 $: \mathrm{D} 0_{19}$ 型規則構造 & & $\beta$ 相 : $\mathrm{Mg}_{23} \mathrm{Th}_{6}$ (面心立方晶) \\
\hline $\mathrm{Mg}-\mathrm{Ca}, \mathrm{Mg}-\mathrm{Ca}-\mathrm{Zn}$ & & & $\mathrm{Mg}_{2} \mathrm{Ca}$ (六方晶), $\mathrm{Zn}$ 添加により微細析出 \\
\hline $\mathrm{Mg}-\mathrm{Ag}-\mathrm{RE}(\mathrm{Nd})$ & $\begin{array}{l}\text { GP ゾーン：棒状および } \\
\text { 回転楕円体状 }\end{array}$ & $\begin{array}{l}\gamma \text { 相: 棒状（六方晶, 整合） } \\
\beta \text { 相: 等軸状（六方晶, 半整合) }\end{array}$ & $\begin{array}{l}\mathrm{Mg}_{12} \mathrm{Nd}_{2} \mathrm{Ag} \text { : 複雑なラス状 } \\
\text { (六方晶, 非整合) }\end{array}$ \\
\hline $\mathrm{Mg}-\mathrm{Sc}$ & - & - & $\mathrm{MgSc}$ \\
\hline
\end{tabular}




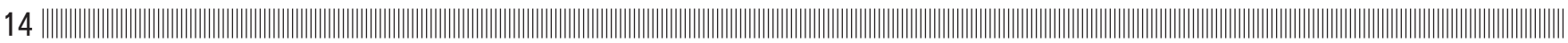

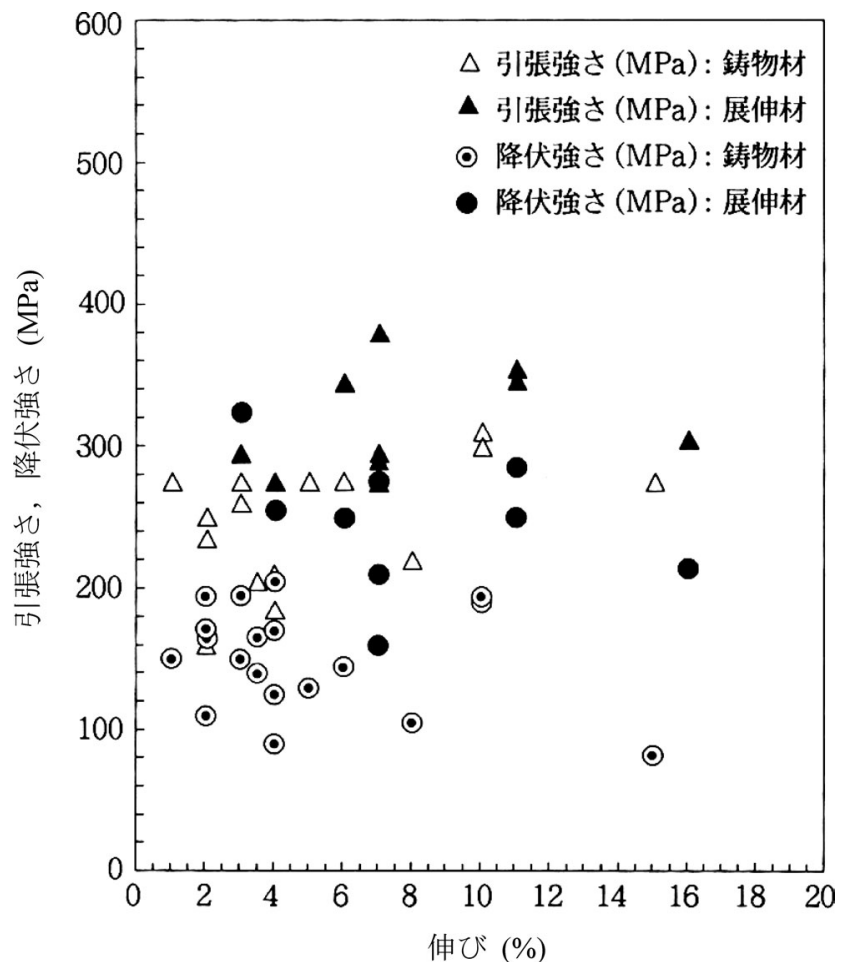

図 16 各種マグネシウム合金の引張強さ，降伏強さと伸 びの関係 ${ }^{15)}$

す ${ }^{15)}$ 。鋳造材と展伸材を比較すると展伸材が強度はやや高 い。また，伸びについては，強度が高いほど伸びはやや小さ くなる傾向にあるが，それほよ゙大きな変化はない。これらの 值が規格に示されている代表的実用マグネシウム合金の標準 的な機械的性質である。

\section{4.おわりに}

マグネシウム合金の熱処理として，特に，時効熱処理につ
いて，基礎現象，各種合金の析出過程ならびに材料特性につ いて述べた。マグネシウム合金の熱処理は, 強度，クリープ 特性，延性などに直接関与し，近年，盛んに研究が行われる ようになった。時効析出の初期現象, 構造変化, 熱的安定性 などの重要項目について, 現在, 必ずしも十分に解明されて いるわけではない。また，様々な微視的ナノ構造についても 研究が進みつつある。さらに, 微量添加元素の役割について 屯系統的解明は十分でない。これらの基礎現象について，今 後, 様々な研究が行われ, 理解が進むあのと思われる。これ によって，より優れた材料特性の合金が開発されることを期 待したい。

\section{参 考 文 献}

1) W. A. Johnson and R. F. Mehl: Trans. AIME, 135 (1939), 416.

2) M. Avrami: J. Chem. Phys., 7 (1939), 1103.

3）堀 茂徳, 浜野 勇, 長畑一拓, 田村 建, 阿倍 睦, 田井英 男：軽金属，44（1994），229-233.

4) A. F. Crawley and K. S. Millken: Acta Met., 22 (1974), 557.

5) J. B. Clark: Acta Met., 16 (1968), 141.

6）渡辺久藤, 河野紀雄, 佐藤英一郎: 千葉工業大学研究報告, 19 (1975), 44.

7) M. M. Avedesian, H. Baker 編 : Magnesium and Magnesium Alloys ( ASM Specialty Handbook), ASM International Handbook Committee, (1999), 78-84.

8）美馬源次郎，田中靖三：日本金属学会誌，33 (1969)，796-800.

9）川野友梨子, 里 達雄: 軽金属学会第 117 回秋期大会講演概要, (2009), 239-240

10) C. J. Bettles, M. A. Gibson and K. Venkatesan: Scripta Mater., 51 (2004), 193-197.

11) P. M. Skjerpe and C. J. Simensen: Metal Science, 17 (1983), 403

12）里＼cjkstart達雄：まてりあ, 38 (1999), 294-297.

13）大森梧郎，松尾 茂，麻田 宏：日本金属学会誌，36（1972）, 1002-1008.

14) I. Polmear: Light Alloys (Fourth Edition), Elsevier, (2006), 277-278.

15）里 達雄：金属，アグネ技術センター，6 (2001)，42-50。 